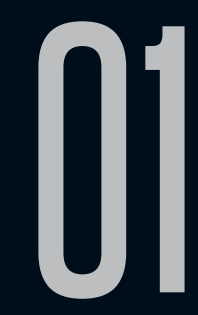

\title{
ODILO (MSS DO SÉC. XXI)
}

Deixavam a bandeja com a marmita do almoço no chão, do outro lado da porta, depois a empregada dava duas pancadinhas na porta, e eu contava até trinta e sete, aguardando que ela continuasse a andar pelo corredor, dando-Ihe tempo para fazer as outras duas entregas e chegar ao elevador. Então, eu abria a porta, puxava a bandeja para dentro, fechando a porta, deitavame no chão e, sem o auxílio dos talheres, comia, bebendo a sopa e apanhando o arroz e a carne ou o peixe com golpes de boca, num chafurdo, como qualquer porco. Depois, daria tudo para terminar a refeição com um café, talvez com uma aguardente bagaceira, velha e olorosa, mas isso estava-me vedado. Corria a lavar o rosto, depois abria a porta e espreitava para ambos os lados do corredor, não estando ninguém, com o pé direito empurrava a bandeja para fora.

É, no entanto, preciso que saibam que estamos todos isolados no mundo inconcebível do nosso lar, não podemos contactar com ninguém, temos os nossos comprimidos, que agora nem paliativos são, mas apenas um engodo, um entretenimento, enquanto suporto inchaços no pescoço, no rosto, sinto queimaduras nos olhos e o nariz sangra todas as tardes, os intestinos parecem 
ter enlouquecido, pois se há dias que padeço de uma desatada desenteria, vejam lá, noutros dias a prisão de ventre parece contribuir para as dores infernais, como se tivesse comido uma pata de dinossauro ou um pedaço de granito gratinado.

A princípio ainda julguei que poderia ler, pois no meu quarto há uma estante com livros religiosos. Aqui era a antiga biblioteca do lar que teve de ser transformada em quarto para eu ser admitido, por interesse do padre Agostinho, e poderia aí encontrar lenitivo para aceitar resignado o sofrimento. Mas sei lá quanto tempo isto ainda vai durar! Nem consegui ver a empregada do lar a quem estou recomendado, porém, imagino-a como extração de aldeã habilitada para atender aos idosos que vivem nesta casa. Idosos? Porra, velhos, gente de terceira classe que quando podia sair do quarto em que estavam recolhidos aos três, se juntavam na sala comum diante do televisor, discutindo que o som deveria estar mais alto ou mais baixo, rogando que a dona sicrana deveria rezar apenas com o movimento dos lábios finos esborratados de batom, mas ela reclamava que assim o seu deus nunca a poderia escutar, e as obscenidades que saiam da boca de um homem de cabeça rapada que passava o seu tempo fazendo crochet ou malha, enganando-se frequentemente na movimentação das agulhas, submetido às gargalhadas secas das duas irmãs que se sentavam junto dele. Uma ainda fazia paciências com as cartas, mas ao fim de uma hora, aparecia um senhor enfermeiro que Ihe tirava o baralho e o levava para um móvel de que apenas ele tinha a chave. Por vezes os velhos erguiam-se ao som de música e, dirigidos por uma animadora, faziam exercidos de ginástica, que os cansava imenso. 
A directora do lar era uma megera, a quem eu designo por sicrana e era D. Leopoldina, pelo menos assim era apontada pela maioria dos utentes. Os velhos torciam os rostos em máscaras horrorosas cada vez que ela voltava as costas e acotovelavam alguma visita que tivessem, acusando-a de todas as culpas. Mas desde que a pandemia obrigou ao confinamento dos hóspedes, nunca mais vimos nem a directora nem o pessoal auxiliar, mas escutávamos os gritos que passavam por baixo das portas, mesmo através das tábuas, um vozear incompreensível que fazia pendant com os cheiros a comida, sobretudo a couves cozidas, bacalhau frito, medicamentos e a urina.

Eu queria um jornal em cada dia, não tenho relógio, nem de pulso nem de móvel, nunca sei as horas e com esta situação é tudo muito estúpido, ninguém vem limpar-me o quarto, dar-me banho, e mesmo abrindo a janela, as roupas e os moveis estão impregnados de um maldito fedor a que se acrescenta o cheiro forte da comida. Ouvimos tocar os sinos da igreja que fica a pouca distância do lar, e como conhecemos bem aquela sonoridade quando tocam a casamentos, a mortos e a baptizados, temos uma ideia aproximada de cadáveres que vão para o tanatório! Eu não vou e aqui não entra ninguém que se encontre infectado, da janela vejo uma nesga de rua, para lá da cerca do jardim sem flores, apenas arvoredo rasteiro.

As pessoas têm o rosto oculto por máscaras e andam inclinadas para diante, bem isto umas vezes que outras parecem ir desabar para a direita. Passam os cães a correr, mas não ladram, e eu bem sei haver automóveis que circulam ilegalmente por estas cercanias. 
Hoje encontrei numa gaveta uma caixa de metal com canetas de feltro e passei a desenhar numa das paredes do meu quarto, onde comecei uma paisagem rural, com um moinho, um rio, uns muares, umas nuvens, que terei de alterar porque as pintei rosadas e deveriam ser escuras. Acabei um garrafão de água mineral e tive de me voltar para a água da torneira, que sabe mal, a cloro. Não consigo dizer a ninguém o que quer que seja, ninguém me fala, ou a quem eu possa falar, e os biscoitos que me trouxe uma assistente social já cheiram e sabem a mofo. Imaginem que cheguei a escrever versos, longos poemas cujo destino é a sanita com o empurrão em forma de parafuso de água no funcionamento do autoclismo.

Os meus livros alinham-se na estante por baixo das prateleiras dos livros da biblioteca do lar, são todos edições de bolso, que escolhi há quatro meses numa livraria de livros em segunda mão, romances de guerra e pouco mais, uns vinte e tantos. Gostaria de ler estes livros de guerra, mas creio que já não tenho coragem. Ou paciência. E eu entrei naquele estabelecimento para me abastecer de romances policiais, mas o preço e o aspecto correspondente dos livros de guerra, novelas, contos, atraiu-me, embora não tivesse começado a ler nenhum. Quando me chega a vontade, abro a porta do guarda-fatos e olho-me no espelho, faço o ar mais sério que posso e trato em pensamento tudo quanto tenho a tratar.

- Senhor Odilo - sussurrou a empregada, desta vez sem bater à porta com as duas pancadinhas do costume. Deixei-me estar encostado à porta, pelo lado de dentro, escutando o seu respirar ofegante, nervoso, sedutor. Não reconheci a rapariga, seria a Mónica ou a Virtudes, decerto se tratava de uma empregada muito 
nova, isso eu adivinhava. Veio mesmo até a mim um cheiro íntimo, saído das profundezas do seu corpo, o que me excitou.

- Senhor Odilo, quer fruta?

Abri repentinamente a porta e puxei a rapariga para dentro do quarto. Ficou em pânico, e a máscara caiu-lhe, uma máscara azul com o logotipo do Lar do Bom Jesus do Campo, junto dos cordõezinhos do lado direito. Quis arrastá-la para a cama, mas esquivou-se, aproveitou a minha fraqueza e deixou-me caído a um canto enquanto fechava de novo a porta, rindo a bandeiras despregadas. Bateu os tacões no sentido contrário ao do elevador, Aonde iria?

Pensei que me queria oferecer uma maçã, pensei que me queria ver enrolado na serpente que a consumia. Desenhei um cão no mural que estava a executar e que decerto me iria custar caro quando, depois do impacto do surto, eu fosse obrigado a abrir a porta, ou eles mesmo arbitrariamente a abririam e se confrontariam, irritadíssimos, com a minha pintura com canetas de feltro.

No entanto, os meses passam, tudo é caduco e ampliam-se os cheiros, o meu pijama escureceu de sujidades, pelo que agora acabo por ter nojo de mim próprio, tanto mais que não consigo reparar as torneiras da casa de banho e receio entrar no duche porque me assaltam o sono as imagens das pessoas a serem assassinadas à facada quando estão do outro lado da cortina de plástico. Suponho que conhecem os filmes.

- Senhor Odilo - era a voz de um homem, não conseguia reconhecê-lo, mas decerto seria um empregado, talvez o que entrara pouco antes da pandemia se manifestar. 
- Senhor Odilo... Senhor Odilo...

Odilo Macedo Pereira sou eu, corri a ver-me ao espelho do guarda-fatos e calculei que a imagem devolvida ainda poderia ser a que me competia desde o início da pandemia. E pensei nos romances de guerra, que talvez um dia fosse obrigado a ler para empatar o tempo, ou mesmo a biografia de um missionário em terras do Oriente, sei lá.

A directora do lar, a sicrana, como eu a chamo para a despojar de qualquer hipótese de importância, caiu nos braços fortes da pandemia, está a morrer. E todos sussurram, mas também deve haver mortes entre nós os utentes, quase aposto.

Porto (Portugal), 2 de outubro de 2020. José Viale Moutinho 